\title{
Pattern of dietary supplement consumption among Iranian high school girls and related factors
}

\author{
Abolfazl Mohammadbeigi ${ }^{1}$, Narges Mohammadsalehi' ${ }^{2}$, Esmail Moshiri ${ }^{3}$, Azadeh Asgarian ${ }^{2}$, Sima \\ Afrashteh $^{4}$, Salman Khazaei ${ }^{5},{ }^{*}$ Hossein Ansari ${ }^{6}$
}

Sri Lanka Journal of Child Health, 2020; 49(1): 41-47

\begin{abstract}
Introduction: Adolescence is a critical period of life especially in high school girls due to large physical, social, and psychological changes.
\end{abstract}

Objectives: To assess prevalence and frequency of consumption of dietary supplements among Iranian high school girls and related factors.

Method: A cross-sectional study was carried out on 638 high school girls in Qom city, Iran in 2017. The girls were selected by multi-stage sampling from 16 high schools. Data were collected using a validated reliable questionnaire that included demographic characteristics and the dietary supplement consumption including ferrous sulphate, folic acid, iron + folic acid, calcium, vitamin $\mathrm{E}$, calcium + vitamin $\mathrm{E}$, zinc, vitamin $\mathrm{C}$, multivitamin and vitamin D. Statistical analysis used SPSS software, Chi square test, independent ttest and multivariate binary logistic regression.

Results: Overall monthly prevalence of dietary supplement consumption was $65.3 \%$ (417/639). Consumption for calcium was $43.2 \%$, for vitamin E

${ }^{1}$ Research Centre of Gastroenterology and Hepatology, ${ }^{2}$ Research Centre for Air Pollutants, Qom University of Medical Sciences, Qom, Iran, ${ }^{3}$ Department of Anaesthesia, School of Medicine, Arak University of Medical Sciences, Arak, Iran, ${ }^{4}$ Department of Public Health, Vice chancellor of Health, MSc of Epidemiology, Bushehr University of Medical Sciences, Bushehr, Iran, ${ }^{5}$ Department of Epidemiology, School of Public Health, Hamadan University of Medical Sciences, Hamadan, Iran, ${ }^{6}$ Health Promotion Research Centre, Department of Epidemiology and Biostatistics, Zahedan University of Medical Sciences, Zahedan, Iran

*Corresponding author: ansarih88@gmail.com

https://orcid.org/0000-0003-2755-7864

(Received on 17 June 2019: Accepted after revision on 19 July 2019)

The authors declare that there are no conflicts of interest

Source of Funding: Qom University of Medical Sciences

Open Access Article published under the Creative

Commons Attribution CC-BY (c) (i) License
$39 \%$, vitamin D $36.5 \%$ ferrous sulphate $35.2 \%$, calcium plus vitamin E $32.6 \%$, iron plus folic acid $25.4 \%$, folic acid $22.4 \%$, multivitamin $20.5 \%$, zinc $17.4 \%$ and vitamin D $8 \%$. The annul prevalence of ferrous sulphate, calcium and vitamin $\mathrm{E}$ was $50 \%$ higher and the minimum prevalence was in vitamin $\mathrm{D}$ and zinc consumption. The regression model showed that income level of family and the SRH score were the most important related factors of dietary supplement consumption.

Conclusions: According to our results, the monthly dietary supplement consumption prevalence in Iranian high school girls is good, but the daily intake of mineral supplement is weak.

DOI: http://dx.doi.org/10.4038/sljch.v49i1.8897

(Key words: Dietary supplement consumption, mineral usage, deficiency, high school girls)

\section{Introduction:}

Adolescence is a sensitive period of life where they experience physical, social, and psychological changes due to pubertal hormones ${ }^{1,2}$. Most adolescent girls have an inadequate micronutrient intake $^{2-4}$. Micronutrient deficiency in adolescent girls may cause impaired growth and development, adverse effect on childbearing, reproductive related complications, cardiovascular and chronic diseases $^{2,3,5}$. Moreover, previous studies have shown an association between the nutrient intake and mental health in adolescence ${ }^{1,6}$.

The recommended dietary reference intakes (DRIs) for supplementation in adolescent girls are 800$2000 \mathrm{IU} /$ day vitamin $\mathrm{D}^{7}, 65 \mathrm{mg}$ vitamin $\mathrm{C}, 400 \mathrm{mcg}$ folate, $15 \mathrm{mg}$ iron, $1300 \mathrm{mg}$ calcium and $9 \mathrm{mg}$ zinc $^{8,9}$. Several factors are related to dietary supplement use such as demographic characteristics, body mass index, pubertal status sun exposure, as well as healthy food consumption with adequate minerals by fruits, vegetables, carbohydrates and proteins ${ }^{10-12}$. Previous studies have shown positive associations between physical activity, calcium intake and bone mass density in females ${ }^{12,13}$. However, fast-food and junk food consumption are inversely related to dietary supplement intake. Some minerals synthesized by human body such as folic acid cannot be produced and have to be obtained through the $\operatorname{diet}^{14}$. 
Iranian studies showed that zinc and vitamin D deficiencies in adolescent women were $8 \%$ and $85 \%{ }^{15}$ respectively, and that daily intake of some minerals in adolescent girls of a central city in Iran was less than $75 \%$ recommended DRI for vitamin B12, vitamin A, folate, calcium, zinc, and fibre ${ }^{8}$. According to recent Iranian studies, prevalence of mineral deficiencies in high school adolescent girls and young women was high ${ }^{16,17}$. Overall prevalence of iron deficiency in a meta-analysis study in Iran was $26.9 \%$ and was higher in young females ${ }^{4}$. Anaemia prevalence due to iron and folic acid deficiency in females was higher than males in Mashhad $^{18}$. Thus, need for dietary supplementation in adolescent high school girls is rational.

\section{Objectives}

To assess the pattern and prevalence of mineral consumption and frequency of dietary supplement consumption among high school girls and related factors in Qom city, Iran in 2017.

\section{Method}

A cross-sectional study was carried out in high school girl students in Qom, a central province of Iran, in 2017. Multi-stage sampling was used for subject selection. Of all girls' high schools in a deprived area of Qom, 16 were selected. In each school, eligible subjects were selected among different majors from governmental versus nongovernmental schools. Finally, 40 students were selected by simple random sampling from each school. Verbal informed consent was taken from all subjects and the study protocol was approved by the ethical committee of Qom University of Medical Sciences.

Data were collected using a standard selfadministered questionnaire in Persian. The content validity was assessed by an expert team. Reliability of questionnaire was evaluated by Cronbach's alpha and estimated to be 0.871 in a pilot study on 50 students. Sample size was calculated based on mineral supplement consumption equal to $66.8 \%$ in a recent study $^{15}$ and alpha error 0.05 . Thus, minimum sample size calculated was 320 and by considering design effect equals 2 , we assessed 640 high school girls, 639 completing questionnaires. The researcher made questionnaire in current study was developed in 2 sections including demographic characteristics such as age, marital status, mother's job and education, and family' income level.

The primary outcome in our study was the dietary supplement consumption in recent month. Therefore, overall dietary supplement consumption evaluated for each subject takes at least one mineral in recent month. Frequency of consumption was assessed in 4 time schedules, namely, every day, every week, every month, and sometimes in year. The dietary supplement consumption regarding all mineral supplements was evaluated for the most common usage minerals including ferrous sulphate, folic acid, iron + folic acid, calcium, vitamin E, calcium + vitamin $\mathrm{E}$, zinc, vitamin $\mathrm{C}$, multivitamin and vitamin $\mathrm{D}$ and was assessed in recent month. This questionnaire was assessed by self-reported health (SRH) and self-reported fitness (SRF) in a five point Likert scale. The two questions were "How do you assess your general health status?" and "How do you assess your body fitness status?" The subjects' responses varied from very $\operatorname{good}=5, \operatorname{good}=4$, moderate $=3$, weak $=2$ and very weak $=1$.

Statistical analysis utilised SPSS software. Prevalence rate of dietary supplement consumption and status of subjects regarding SRH and SRF were presented using descriptive statistics. Chi square test was used to assess relationship between supplement consumption and qualitative variables. Independent t-test was used to evaluate difference of mean and standard deviation between two groups (consumed and not consumed). Multivariate binary logistic regression was used to determine most important related factors of dietary supplement consumption. Marital status, maternal education, family income level and SRH score were the variables included in the regression model. $\mathrm{p}<0.05$ was considered significant.

\section{Results}

The demographic characteristics of the studied high school girls in Qom city are shown in Table 1.

Table 1: Demographic characteristics of studied high school girls in Qom city $(n=639)$

\begin{tabular}{|l|c|}
\hline \multicolumn{1}{|c|}{ Variable } & Number (\%) \\
\hline Marital status & $616(96.4)$ \\
Single & $23(03.6)$ \\
\hline Majoried & $246(38.5)$ \\
Experimental sciences & $175(27.4)$ \\
Human sciences & $218(34.1)$ \\
Mathematical/Skill & \\
sciences & \\
\hline Mother's job & $31(04.9)$ \\
Staff & $574(90.4)$ \\
Homemaker & $30(04.7)$ \\
Other & \\
\hline Mother's education & $105(16.5)$ \\
Illiterate & $290(45.7)$ \\
Elementary & $168(26.5)$ \\
High school & $72(11.3)$ \\
College & \\
\hline Income level (per month) & $312(53.4)$ \\
Less than 250\$ & $144(24.7)$ \\
250-499\$ & $64(11.0)$ \\
500-750\$ & $64(11.0)$ \\
More than 750\$ & \\
\hline
\end{tabular}


The mean age of subjects was $15.77 \pm 0.73$ years and ranged from 15-18 years. In addition, the mean ages of menarche and body mass index (BMI) were $12.70 \pm 1.34$ years and $20.85 \pm 3.29 \mathrm{~kg} / \mathrm{m}^{2}$, respectively. The overall monthly prevalence of dietary supplement consumption was calculated as $65.3 \%(417 / 639)$.

In addition, the prevalence of mineral supplement consumption in one recent month (Figure 1) was estimated for calcium $43.2 \%$, vitamin E 39\%, vitamin D $36.5 \%$, ferrous sulphate $35.2 \%$, calcium plus vitamin E $32.6 \%$, iron plus folic acid $25.4 \%$, folic acid $22.4 \%$, multivitamin $20.5 \%$, zinc $17.4 \%$ and vitamin D $8 \%$. Moreover, the annul prevalence of dietary supplement consumption among high school girls of Qom city is presented in table 2. The annual prevalence of ferrous sulphate, calcium and vitamin $\mathrm{E}$ was $50 \%$ higher and the minimum prevalence was in vitamin D and zinc consumption. Nevertheless, the frequency of dietary supplement consumption varied among different mineral consumption as shown in table 2 .

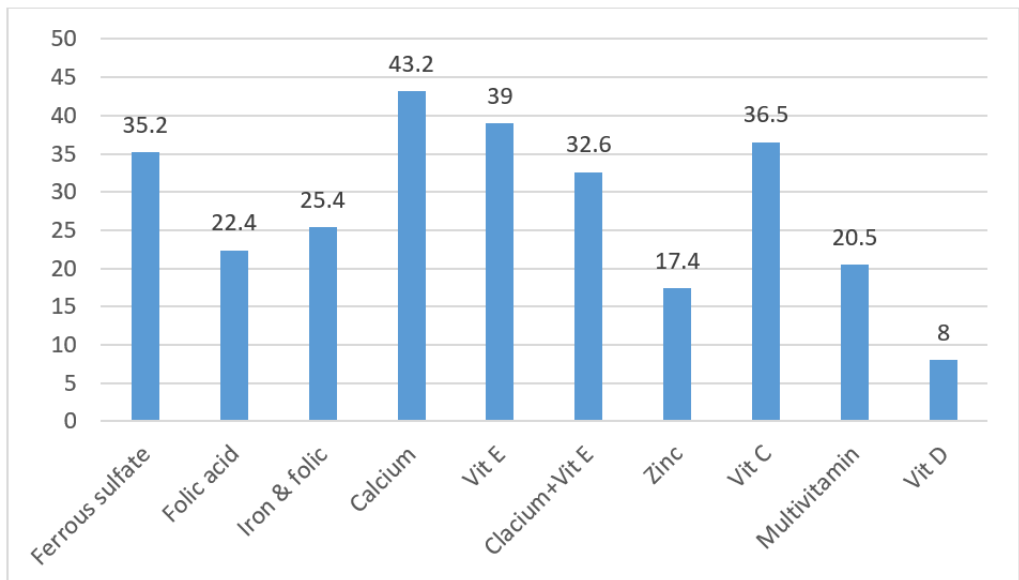

Figure 1: The monthly usage of mineral supplementation in high school girls of study

Table 2

Prevalence and frequency of dietary supplement consumption among Qom high school girl students (n=639)

\begin{tabular}{|l|c|c|c|c|}
\hline \begin{tabular}{c} 
Pattern of consumption $\begin{array}{c}\text { of mineral and vitamin } \\
\text { supplements }\end{array}$ \\
\cline { 2 - 5 }
\end{tabular} & $\begin{array}{c}\text { Supplement consumption } \\
\text { never }(\%)\end{array}$ & $\begin{array}{c}\text { Yes } \\
\mathbf{n}(\%)\end{array}$ & $\begin{array}{c}\text { Frequency of supplement consumption } \\
\text { Every day }\end{array}$ & $\begin{array}{c}\text { Every week } \\
\text { n (\%) }\end{array}$ \\
\hline Ferrous sulphate & $265(41.5)$ & $374(58.5)$ & $70(11.0)$ & $102(16.0)$ \\
\hline Folic acid & $412(64.5)$ & $227(35.5)$ & $39(06.1)$ & $66(10.3)$ \\
\hline Iron + folic acid & $379(59.3)$ & $260(40.7)$ & $48(07.5)$ & $68(10.6)$ \\
\hline Calcium & $288(45.1)$ & $351(54.9)$ & $37(05.8)$ & $102(16.0)$ \\
\hline Vitamin E & $311(48.7)$ & $328(51.3)$ & $43(06.7)$ & $76(11.9)$ \\
\hline Calcium + vitamin E & $355(55.6)$ & $284(44.4)$ & $35(05.5)$ & $43(12.2)$ \\
\hline Zinc & $458(71.7)$ & $181(28.3)$ & $29(04.5)$ & $88(13.8)$ \\
\hline Vitamin C & $331(51.8)$ & $308(48.3)$ & $28(04.4)$ & $55(08.6)$ \\
\hline Multivitamin & $418(65.4)$ & $221(34.6)$ & $34(05.3)$ & $15(02.3)$ \\
\hline Vitamin D & $504(78.9)$ & $135(21.1)$ & $19(03.0)$ & \\
\hline
\end{tabular}

The association of demographic characteristics with dietary supplement consumption was assessed and presented in table 3 . According to these results, a significant difference was showed by Chi Square test in two groups based on maternal education and income level of family. Moreover, independent ttest showed that the mean of SRH and SRF scores was statistically significant between girls who have dietary supplement consumption and others $(p<0.05)$. Nevertheless, there was no significant difference between two groups regarding, age, BMI, menarche age, educational major, marital status and maternal job ( $\mathrm{p}>0.05)$.
The multivariate logistic regression (table 4) showed that the most important related factors of dietary supplement consumption among Qom high school girls were the income level of family and the SRH score. Based on our results, by increasing the level of family income the odds of supplement consumption increased to $50 \%$ in second level in comparison to first level. Moreover, the odds ratio of girls in highest level income was 2.1 in comparison to first income level. The SRH score showed a significant direct relationship with supplement consumption. By increasing one score in SRH, the odds of supplement consumption increased to $61 \%$. 
Table 3: Related factors of dietary supplement consumption among Qom high school girls

\begin{tabular}{|c|c|c|c|}
\hline Variable & $\begin{array}{c}\text { No supplement } \\
\text { consumed }\end{array}$ & $\begin{array}{c}\text { Supplement } \\
\text { consumed }\end{array}$ & p-value \\
\hline $\begin{array}{l}\text { Marital status n }(\%) \\
\text { Single } \\
\text { Married }\end{array}$ & $\begin{array}{c}210(34.1) \\
12(52.2)\end{array}$ & $\begin{array}{c}406(65.9) \\
11(47.8)\end{array}$ & $0.069 \dagger$ \\
\hline $\begin{array}{l}\text { Educational Major } \mathrm{n}(\%) \\
\text { Experimental } \\
\text { Human } \\
\text { Mathematical }\end{array}$ & $\begin{array}{l}85(34.6) \\
56(32.0) \\
81(37.2)\end{array}$ & $\begin{array}{l}161(65.4) \\
119(68.0) \\
137(62.8) \\
\end{array}$ & $0.564 \dagger$ \\
\hline $\begin{array}{l}\text { Mother's job n (\%) } \\
\text { Staff } \\
\text { Housemaker }\end{array}$ & $\begin{array}{c}07(22.6) \\
213(35.3) \\
\end{array}$ & $\begin{array}{c}24(77.4) \\
391(64.7) \\
\end{array}$ & $0.103 \dagger$ \\
\hline $\begin{array}{l}\text { Mother's education } \mathrm{n}(\%) \\
\text { Elementary/illiterate } \\
\text { High school } \\
\text { College }\end{array}$ & $\begin{array}{l}152(38.5) \\
57(33.9) \\
13(18.1) \\
\end{array}$ & $\begin{array}{c}243(61.5) \\
111(66.1) \\
59(81.9) \\
\end{array}$ & $0.004 \dagger$ \\
\hline $\begin{array}{l}\text { Income level of family n (\%) } \\
\text { Less than } 249 \$ \\
250-499 \$ \\
\text { More than } 500 \$\end{array}$ & $\begin{array}{l}127(40.7) \\
43(29.9) \\
29(22.7)\end{array}$ & $\begin{array}{l}185(59.3) \\
101(70.1) \\
99(77.3)\end{array}$ & $0.001 \uparrow$ \\
\hline Age $($ mean $\pm \mathrm{SD})$ & $15.75 \pm 0.75$ & $15.79 \pm 0.72$ & $0.577 \$$ \\
\hline SRH Score mean \pm SD (median, IQR) & $1.56 \pm 0.75(1.1,1-2)$ & $1.91 \pm 0.94(1.5,1-2)$ & $0.001 \ddagger$ \\
\hline SRF Score mean \pm SD (median, IQR) & $1.88 \pm 0.97(1.5,1-3)$ & $2.13 \pm 1.06(2,1-3)$ & $0.003+$ \\
\hline $\mathrm{BMI}($ mean $\pm \mathrm{SD})$ & $21.13 \pm 3.45$ & $20.96 \pm 3.25$ & $0.586+$ \\
\hline Menarche age (mean \pm SD) & $12.72 \pm 1.30$ & $12.69 \pm 1.36$ & $0.848 \div$ \\
\hline
\end{tabular}

$\uparrow$ Chi Square test

\$ Independent t-test

Table 4: Results of multivariate logistic regression of related factors of dietary supplement consumption among Qom high school girls

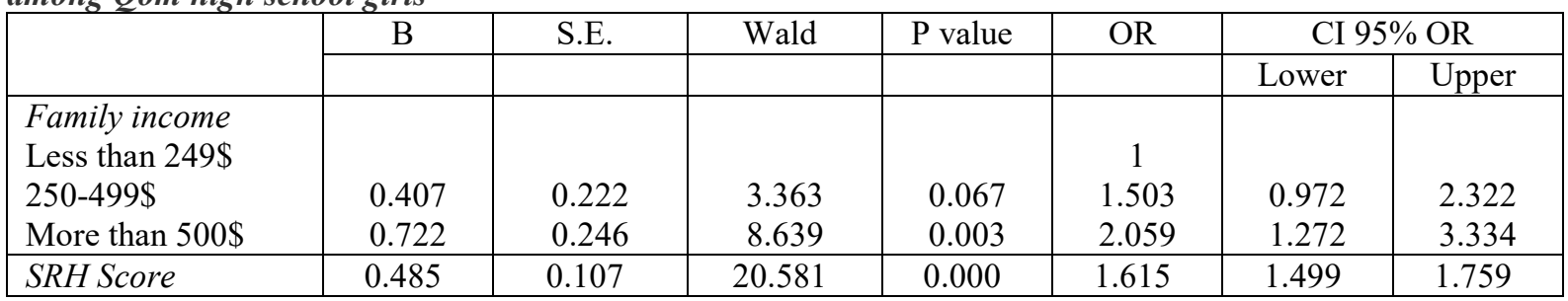

\section{Discussion:}

The overall monthly prevalence of dietary supplement consumption in our study was $65.3 \%$. Estimated monthly prevalence for calcium was $43.2 \%$, for vitamin E 39\%, for vitamin D 36.5\%, for ferrous sulphate $35.2 \%$, for calcium plus vitamin E $32.6 \%$, for iron plus folic acid $25.4 \%$, for folic acid $22.4 \%$, for multivitamin $20.5 \%$, for zinc $17.4 \%$ and for Vitamin D $8 \%$, respectively. These results showed that the dietary mineral supplement use in Iranian high school girls is good based on the mineral deficiencies in our communities. The results of a systematic review and a multicentre study in 13 European countries based data of national surveys showed that inadequate intake of selected nutrients was highly prevalent ${ }^{20,21}$. These included vitamin $\mathrm{C}$ intake from $8-40 \%$; vitamin $\mathrm{D}$ from $47-100 \%$; vitamin B12 from $0-40 \%$; folic acid from $10-91 \%$; calcium from $0-61 \%$; iron from 0 $18 \%$ and zinc from $1-31 \%$ in adults aged 19 to 64 years ${ }^{21}$. Similar data are available from the United States $^{22}$. Moreover, a community based crosssectional study in five schools in Udupi Taluk on 422 adolescent girls revealed that most adolescent girls had greatly insufficient intake of numerous micronutrients including iron and calcium ${ }^{2}$. Another study in an Australian university population showed that more than $70 \%$ of participants used at least one type of dietary supplement in the past 6 months ${ }^{10}$.

The Belgian Food Consumption survey on the Belgian adult population showed that more than $10 \%$ of the study subjects used at least one of two $24-\mathrm{h}$ dietary recall days ${ }^{23,24}$. In our study $44.9 \%$ of subjects reported that they used at least one type of dietary supplements from 10 different ones in recent 24 hours. Although some dietary supplements prescribing and using occurred during illness or injury ${ }^{10}$, in our study the prevalence of 
affecting diseases was low. Moreover, overuse of nutrient supplements may have negative results and inverse benefit. The uncontrolled mineral supplement use could cause neurological, gastrointestinal, liver and kidney toxicity ${ }^{23}$.

Vitamin D deficiency was fourfold commoner in female students than in male students $(72.1 \%$ versus $18.3 \%)^{16}$. Another study showed that prevalence of mild, moderate and severe vitamin D deficiency among adults of Isfahan was $19.6 \%$, $23.9 \%$, and $26.9 \%$ respectively and that it was more prevalent among females and youth ${ }^{17}$. Another study in Turkish girls showed mineral intakes less than two-thirds of the RDA in $26.8 \%$ compared to $59.1 \%$ in Spanish adolescent girls ${ }^{14}$.

Adolescence is a critical period that causes major alterations in the human body including gaining $20 \%$ of their height and $50 \%$ of their weight and skeletal mass ${ }^{12}$. Therefore, the mineral consumption has a facilitator role in growth and metabolism ${ }^{12,14}$, and vitamin intake is essential for growth and development of adolescents. However, a Cochrane review showed that mineral supplementation in young females, especially in low- to middle-income countries, before marriage and pregnancy, is important and could decrease the prevalence of low birth weight and preterm delivery ${ }^{6}$.

Based on our results the weak perception of participants in our study about their health status and the low income level were significant factors that were the most important predictors of insufficient mineral use. Similar results were shown in other studies ${ }^{11,19,25,26}$. The Oner study in 704 adolescent Turkish girls showed that based on logistic regression analysis, low income level increases the mineral deficiency 2.4 fold $^{14}$. In addition, the Barnes et al study in Australian university population showed that the common reasons for using of a specific dietary supplement were the general health status ${ }^{10}$. Our results also showed that the self-rated health is the most important predictor of dietary supplement consumption.

Despite some limitations in our study, this research elicited some important information regarding mineral consumption prevalence and the important factors related with insufficient intake of mineral. According to our results, educational programmes for improving the nutritional habits including consuming high-quality protein from meat and milk products, enough fruits and vegetables to maintain daily vitamin, mineral, and fibre requirements are needed and major changes are essential in health care that provided for adolescent girls and those proportion of unmarried high school girls. However, nutritional education is an effective factor to motivate adolescents in using healthy food choices. However, there is need for regular sensitizing nutritional programs at school, especially in girls' high school, to prevent reproductive related complications in their future life.

\section{Conclusions}

According to our results, the monthly dietary supplement consumption prevalence in Iranian high school girls is good, but the daily intake of mineral supplement is weak.

\section{Acknowledgements}

The authors are very grateful for research ViceChancellor of Qom University of Medical Sciences as well as all girls who participated in the study.

\section{References}

1. Kim T-H, Choi J-y, Lee H-H, Park Y. Associations between dietary pattern and depression in Korean adolescent girls. Journal of Pediatric and Adolescent Gynecology 2015; 28(6):533-7. https://doi.org/10.1016/j.jpag.2015.04.005 PMid:26324576

2. Gupta A, Noronha JA, Shobha, Garg M. Dietary intake of macronutrients and micronutrients among adolescent girls: A cross sectional study. Clinical Epidemiology and Global Health 2018; 6:192-7.

https://doi.org/10.1016/j.cegh.2018.02.010

3. Shahla A, Charehsaz S, Talebi R, Omrani M. Vitamin D deficiency in young females with musculoskeletal complaints in Urmia, northwest of Iran. Iranian Journal of Medical Sciences 2015; 30(2).

4. Akbari M, Moosazadeh M, Tabrizi R, Khatibi SR, Khodadost M, Heydari ST, et al. Estimation of iron deficiency anemia in Iranian children and adolescents: a systematic review and meta-analysis. Hematology 2017; 22(4):231-9.

https://doi.org/10.1080/10245332.2016.12 40933

PMid:27741938

5. Gonoodi K, Moslem A, Darroudi S, Ahmadnezhad M, Mazloum Z, Tayefi M, et al. Serum and dietary zinc and copper in Iranian girls. Clinical Biochemistry 2018; 54:25-31. 
https://doi.org/10.1016/j.clinbiochem.201

8.02 .006

PMid:29438682

6. Haider BA, Bhutta ZA. Multiplemicronutrient supplementation for women during pregnancy. Cochrane Database Systematic Reviews 2015;11(4):

https://doi.org/10.1002/14651858.CD0049 05.pub4

7. Rusińska A, Płudowski P, Walczak M, Borszewska-Kornacka MK, Bossowski A, Chlebna-Sokół D, et al. Vitamin D supplementation guidelines for general population and groups at risk of vitamin D deficiency in Poland-Recommendations of the Polish Society of Pediatric Endocrinology and Diabetes and the Expert Panel With Participation of National Specialist Consultants and Representatives of Scientific Societies2018 Update. Front Endocrinol (Lausanne). 2018;9:246

https://doi.org/10.3389/fendo.2018.00246

PMid:29904370 PMCid:PMC5990871

8. Doustmohammadian A, Keshavarz SA, Doustmohammadian S, Abtahi M, Shahani M. Nutritional status and dietary intake among adolescent girls. Journal of Paramedical Sciences.2013; 4:

9. Mirzaeian S, Ghiasvand R, Sadeghian F, Sheikhi M, Khosravi Z, Askari G, et al. Assessing the micronutrient and macronutrient intakes in female students and comparing them with the set standard values. Journal of Education and Health Promotion 2013; 2(1):1-.

https://doi.org/10.4103/2277-9531.106636 PMid:24083251 PMCid:PMC3778563

10. Barnes K, Ball L, Desbrow B, Alsharairi $\mathrm{N}$, Ahmed F. Consumption and reasons for use of dietary supplements in an Australian university population. Nutrition 2016; 32(5):524-30.

https://doi.org/10.1016/j.nut.2015.10.022 PMid:26819063

11. Saki F, Dabbaghmanesh MH, Omrani GR, Bakhshayeshkaram M. Vitamin D deficiency and its associated risk factors in children and adolescents in southern Iran. Public Health Nutrition 2017; 20(10): 1851-6. https://doi.org/10.1017/S13689800150019 25

PMid:26051113
12. Öner N, Vatansever Ü, Garipağaoğlu M, Karasalihoğlu S. Dietary intakes among Turkish adolescent girls. Nutrition Research 2005; 25(4):377-86.

https://doi.org/10.1016/j.nutres.2005.01.0 02

https://doi.org/10.1016/j.nutres.2005.01.0 02

13. Bush RA. Female high-school varsity athletics: An opportunity to improve bone mineral density. Journal of Science and Medicine in Sport 2009; 12(3):366-70. https://doi.org/10.1016/j.jsams.2008.01.00 4

PMid:18356106

14. Öner N, Vatansever Ü, Karasalihoğlu S, Ekuklu G, Çeltik C, Biner B. The prevalence of folic acid deficiency among adolescent girls living in Edirne, Turkey. Journal of Adolescent Health 2006; 38(5):599-606.

https://doi.org/10.1016/j.jadohealth.2005.0 3.027

PMid: 16635773

15. Pouraram H, Djazayery A, Mohammad K, Parsaeian M, Abdollahi Z, Dorosty Motlagh A, et al. Second National Integrated Micronutrient Survey in Iran: Study Design and Preliminary Findings. Archives of Iranian Medicine 2018; 21(4):137-44.

16. Moussavi M, Heidarpour R, Aminorroaya A, Pournaghshband Z, Amini M. Prevalence of vitamin D deficiency in Isfahani high school students in 2004. Hormone Research in Paediatrics 2005; 64(3): 144-8.

https://doi.org/10.1159/000088588 PMid:16192739

17. Hovsepian S, Amini M, Aminorroaya A, Amini P, Iraj B. Prevalence of Vitamin D Deficiency among Adult Population of Isfahan City, Iran. Journal of Health, Population, and Nutrition 2011; 29(2):149-55.

https://doi.org/10.3329/jhpn.v29i2.7857

PMid: 21608424

18. Eftekharzadeh-Mashhadi I, HedayatiMoghaddam MR, Fathimoghadam F, Bidkhori HR, Shamsian SK. Anemia as a public health issue in Mashhad, Iran: evidence from the first population-based study. Acta Medica Iranica 2015; 53(3): 186 . 
19. Fattahzadeh-Ardalani G, Farzaneh E, Fathi A, Molaei B, Valizadeh M. Determining the prevalence of dietary supplement consumption among Ardabil University students and related factors, 2014. International Journal Of Community Medicine And Public Health 2017; 3(1):224-9.

https://doi.org/10.3329/jhpn.v29i2.7857 PMid:21608424

20. Biesalski HK, Tinz J. Multivitamin/mineral supplements: Rationale and safety - A systematic review. Nutrition 2017; 33:76-82. https://doi.org/10.1016/j.nut.2016.02.013 PMid:27553772

21. Viñas BR, Barba LR, Ngo J, Gurinovic M, Novakovic R, Cavelaars A, et al. Projected prevalence of inadequate nutrient intakes in Europe. Annals of Nutrition and Metabolism 2011; 59(24):84-95.

https://doi.org/10.1159/000332762

PMid:22142665

22. Wallace T, McBurney M, Fulgoni VI. Multivitamin/mineral supplement contribution to micronutrient intakes in the United States, 2007-2010. Journal of the American College of Nutrition 2014; 33:94-102.

https://doi.org/10.1080/07315724.2013.84 6806

PMid:24724766
23. Huybrechts I, Maes L, Vereecken C, De Keyzer W, De Bacquer D, De Backer G, et al. High dietary supplement intakes among Flemish preschoolers. Appetite 2010; 54(2):340-5. https://doi.org/10.1016/j.appet.2009.12.01 2

PMid:20043963

24. De Vriese S, Huybrechts I, Moreau M, Van Oyen H. The Belgian Food Consumption Survey 1-2004: report (Enque te de consommation alimentaire Belge 1-2004: Rapport) 2006.

25. Knapik JJ, Trone DW, Austin KG, Steelman RA, Farina EK, Lieberman HR. Prevalence, Adverse Events, and Factors Associated with Dietary Supplement and Nutritional Supplement Use by US Navy and Marine Corps Personnel. Journal of the Academy of Nutrition and Dietetics 2016; 116(9):1423-42.

https://doi.org/10.1016/j.jand.2016.02.015 PMid:27083989

26. O’Brien SK, Malacova E, Sherriff JL, Black LJ. The Prevalence and Predictors of Dietary Supplement Use in the Australian Population. Nutrients 2017; 9(10): 1154 .

https://doi.org/10.3390/nu9101154

PMid:29065492 PMCid:PMC5691770 